\title{
Metal Preferences of Zinc-Binding Motif on Metalloproteases
}

\author{
Kayoko M. Fukasawa, ${ }^{1}$ Toshiyuki Hata, ${ }^{2}$ Yukio Ono, ${ }^{2}$ and Junzo Hirose ${ }^{2}$ \\ ${ }^{1}$ Department of Hard Tissue Research, Graduate School of Oral Medicine, Matsumoto Dental University, Shiojiri, \\ Nagano 399-0781, Japan \\ ${ }^{2}$ Faculty of Pharmacy and Pharmaceutical Science, Fukuyama University, Gakuen-cho, Fukuyama 729-0292, Japan \\ Correspondence should be addressed to Kayoko M. Fukasawa, kmf@po.mdu.ac.jp \\ Received 4 October 2010; Revised 25 January 2011; Accepted 7 March 2011 \\ Academic Editor: Shandar Ahmad
}

Copyright (๑) 2011 Kayoko M. Fukasawa et al. This is an open access article distributed under the Creative Commons Attribution License, which permits unrestricted use, distribution, and reproduction in any medium, provided the original work is properly cited.

\begin{abstract}
Almost all naturally occurring metalloproteases are monozinc enzymes. The zinc in any number of zinc metalloproteases has been substituted by some other divalent cation. Almost all Co(II)- or Mn(II)-substituted enzymes maintain the catalytic activity of their zinc counterparts. However, in the case of $\mathrm{Cu}$ (II) substitution of zinc proteases, a great number of enzymes are not active, for example, thermolysin, carboxypeptidase A, endopeptidase from Lactococcus lactis, or aminopeptidase B, while some do have catalytic activity, for example, astacin (37\%) and DPP III (100\%). Based on structural studies of various metal-substituted enzymes, for example, thermolysin, astacin, aminopeptidase B, dipeptidyl peptidase (DPP) III, and del-DPP III, the metal coordination geometries of both active and inactive $\mathrm{Cu}$ (II)-substituted enzymes are shown to be the same as those of the wild-type $\mathrm{Zn}$ (II) enzymes. Therefore, the enzyme activity of a copper-ion-substituted zinc metalloprotease may depend on the flexibility of catalytic domain.
\end{abstract}

\section{Introduction}

Proteolytic enzymes are recognized by their catalytic type, that is, aspartic, cysteine, metallo, serine, threonine, and others as yet unclassified. The largest number of proteolytic enzymes are classified as metalloproteases [1]. Almost all metalloproteases contain one or two zinc ions, and several enzymes contain one or two cobalt or manganese ions. The HExxH motif forming an $\alpha$-helix is well conserved in many monozinc enzymes as the active site in which the two histidine residues coordinate with the zinc ion [2]. Some other monozinc proteases have different zinc-binding motifs, for example, $\operatorname{HxxE}(\mathrm{D})-\mathrm{aa}_{\mathrm{n}}-\mathrm{H}$ in the carboxypeptidase family or $\mathrm{HxD}-\mathrm{aa}_{12}-\mathrm{H}-\mathrm{aa}_{12}-\mathrm{H}$ in the matrix metalloprotease family [2]. Dipeptidyl peptidase (DPP) III also has a unique zincbinding motif, which was classified as family M49 in 1999 by MEROPS (peptidase database) after rat DPP III had been cloned and the HELLGH motif of DPP III was identified as an active site coordinated with a zinc ion $[3,4]$. Although the motif HELLGH could not be found in any other metalloproteases, it exists in three kinds of monooxygenases (tyrosine, phenylalanine, and tryptophan hydroxylases) as an iron-binding site, as revealed by a search of the NBRF-PIR protein sequence database.

Zinc atoms in several zinc metalloproteases, for example, astacin [5], carboxypeptidase A [6], and thermolysin [7, 8], have been substituted by other divalent cations to probe the role of the metal for catalysis and structure. Some of these enzymes, for example, DPP III and astacin, were shown to have high metal substitution tolerance by metal substitution studies [9]. However, it is difficult to determine the relationship between the metal tolerance and the metal coordination structure of zinc metalloproteases.

Here, we show the metal coordination structure of the unique zinc-binding motif of DPP III, in which the zinc-binding motif is stabilized by several hydrogen bonds with acidic amino acid residues surrounding the zincbinding motif, in order to clarify the relationship between the metal tolerance and the structure of the zinc-binding domain. The metal tolerances of both DPP III and del-DPP III, whose active site converts into a normal zinc-binding motif (HExxH), are shown here and compared with those 
TABLE 1: The zinc coordination residues and the residues that fix the coordination with hydrogen bonds.

\begin{tabular}{|c|c|c|c|}
\hline Zinc metalloprotease & $\begin{array}{l}\text { Coordination } \\
\text { residues }\end{array}$ & $\begin{array}{l}\text { Residues that form the hydrogen bond } \\
\text { with the coordination residues }\end{array}$ & PDB no. \\
\hline (1) Thermolysin type & $\left(\mathrm{HExxH}-\mathrm{aa}_{\mathrm{n}}-\mathrm{E}\right)$ & $\alpha$-helix-aa $a_{n}-\alpha$-helix & \\
\hline Thermolysin & His $^{142}$, His $^{146}$ Glu $^{166}$ & $\begin{array}{l}\text { Asp }^{170}-2.8 \AA-\mathrm{His}^{142} \\
\text { Asn }^{165}-2.8 \AA-\mathrm{His}^{146}\end{array}$ & $1 \mathrm{KEI}$ \\
\hline Vibriolysin & $\mathrm{His}^{345}, \mathrm{His}^{349} \mathrm{Glu}^{369}$ & $\begin{array}{l}\mathrm{Asp}^{373}-2.8 \AA-\mathrm{His}^{345} \\
\mathrm{Asn}^{368}-2.8 \AA-\mathrm{His}^{349}\end{array}$ & $3 N Q X$ \\
\hline $\begin{array}{l}\text { Staphylococcus aureus } \\
\text { metalloproteinase }\end{array}$ & His $^{144}$, His $^{148}$ Glu $^{168}$ & $\begin{array}{l}\text { Asn }{ }^{167}-2.8 \AA-\mathrm{His}^{148} \\
\text { Asp }^{172}-2.8 \AA-\mathrm{His}^{144}\end{array}$ & $1 \mathrm{BQB}$ \\
\hline Zinc aminopeptidase & His $^{265}$, His $^{269}$ Glu $^{288}$ & $\mathrm{Ph}^{272}(\mathrm{C}=\mathrm{O})-2.9 \AA \AA-\mathrm{His}^{269}$ & $1 \mathrm{Z1W}$ \\
\hline Leukotriene A4 hydrolase & His $^{295}$, His $^{299}$ Glu $^{318}$ & $\begin{array}{c}\mathrm{Glu}^{325}-2.8 \AA-\mathrm{His}^{295} \\
\mathrm{Gly}^{303}(\mathrm{C}=\mathrm{O})-2.6 \AA-\mathrm{His}^{299}\end{array}$ & 1SQM \\
\hline Human thimet oligopeptidase & $\mathrm{His}^{473}, \mathrm{His}^{477} \mathrm{Glu}^{502}$ & $\mathrm{Glu}^{509}-2.6 \AA-\mathrm{His}^{473}$ & 1SQM \\
\hline $\begin{array}{l}\text { Human neutral endopeptidase } \\
\text { (Neprilysin) }\end{array}$ & $\mathrm{His}^{583}, \mathrm{His}^{587} \mathrm{Glu}^{646}$ & $\begin{array}{l}\text { Asp }^{650}-2.9 \AA-\mathrm{His}^{583} \\
\text { Asp }^{590}-2.7 \AA-\mathrm{His}^{587}\end{array}$ & 1DMT \\
\hline (2) Endopeptidase type & & $\begin{array}{c}\left(\mathrm{HExxH}-\mathrm{aa}_{\mathrm{n}}-\mathrm{E} \text { or } \mathrm{D}\right) \\
\alpha \text {-helix-aa } \\
\text { - }- \text { random coil }\end{array}$ & \\
\hline Peptidyl-Lys metalloendopeptidase & His $^{117}$, His $^{121}$ Asp $^{130}$ & $\begin{array}{c}\operatorname{Asp}^{154}-2.7 \AA-\mathrm{His}^{117} \\
\operatorname{Thr}^{128}(\mathrm{C}=\mathrm{O})-2.8 \AA-\mathrm{His}^{121}\end{array}$ & 1GE6 \\
\hline (3) Carboxypeptidase A type & & $\beta$-sheet-aa ${ }_{\mathrm{n}}$-random coil & \\
\hline Carboxypeptidase A & His $^{69}$, His $^{196}$ Glu $^{72}$ & Asp $^{142}-2.7 \AA-\mathrm{His}^{69}$ & $1 \mathrm{YME}$ \\
\hline Putative lysostaphin peptidase & $\mathrm{His}^{232}, \mathrm{His}^{311} \mathrm{Asp}^{236}$ & $\begin{array}{c}\mathrm{Glu}^{315}-2.6 \AA-\mathrm{His}^{311} \\
\mathrm{Gly}^{216}(\mathrm{C}=\mathrm{O})-2.8 \AA-\mathrm{His}^{232}\end{array}$ & 2GU1 \\
\hline
\end{tabular}

reported for other metalloproteases [10]. Finally, we discuss the relationship between the catalytic activities and metal coordination structures of metal-substituted enzymes.

\section{Identification of a Zinc-Binding Motif in DPP III}

We start with the identification of the zinc-binding motif in DPP III, which will be used for further investigation of the relationship between the metal tolerance and the metal coordination structures of DPP III. The deduced amino acid sequences from cDNA for human, rat, and fruit fly DPP IIIs are 723-738 amino acids long and conserve the amino acid sequence HELLGH-aa $52-\mathrm{E}[3,11,12]$, which resembles the $\mathrm{HExxH}-\mathrm{aa}_{\mathrm{n}}-\mathrm{E}$ zinc-binding motif conserved in many metalloproteases, such as thermolysin [13] and leukotriene $\mathrm{A}_{4}$ hydrolase [14]. Site-directed mutagenesis was performed on rat DPP III in order to testify that the HELLGH-aa ${ }_{52}-\mathrm{E}$ is a zinc-binding domain. Site-directed mutagenesis studies have clearly shown that the H450Y, H455Y, and E508A mutants, which lack zinc ions, lose their catalytic activity [4]. Replacement of $\mathrm{Glu}^{451}$ in these mutants with an alanine or an aspartic acid restores a mol of zinc ion per mol of protein but does not restore catalytic activity [4]. These results show that the $\mathrm{H}^{450} \mathrm{ELLGH}-\mathrm{aa}_{52}-\mathrm{E}^{508}$ motif is a catalytic domain of which $\mathrm{His}^{450}$, $\mathrm{His}^{455}$, and $\mathrm{Glu}^{508}$ are ligands of a zinc ion and of which $\mathrm{Glu}^{451}$ is a catalytic amino acid residue, in the same way that the $\mathrm{H}^{142} \mathrm{ExxH}-\mathrm{aa}_{19}-\mathrm{E}^{166}$ motif of thermolysin is a catalytic domain of which $\mathrm{His}^{142}$ His $^{146}$, and Glu ${ }^{166}$ are ligands of a zinc ion and $\mathrm{Glu}^{143}$ is a catalytic amino acid residue.

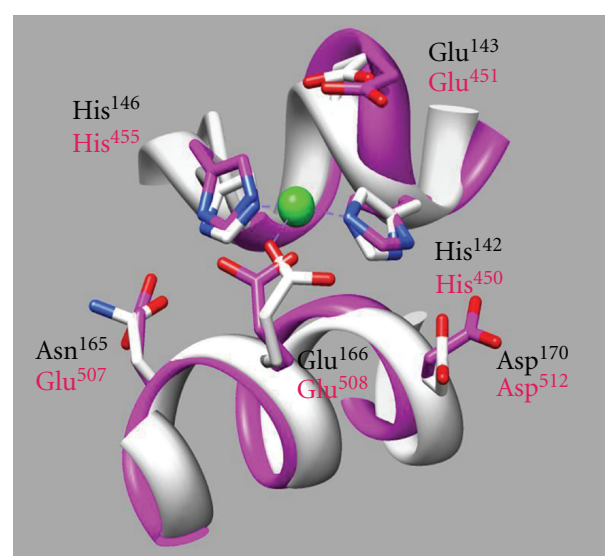

FIGURE 1: The superimposition of the active sites of rat DPP III and thermolysin. Zinc ion is shown as a green sphere, and amino acid side chains are shown as sticks colored red for oxygen and blue for nitrogen. Metal coordinates in light blue and hydrogen bonds in yellow are indicated by dashed lines. Carbon atom and amino acid chain are shown colored white for thermolysin and magenta for DPP III. Metal coordination bonds are indicated by light blue dashed lines.

The 1.95- $\AA$ crystal structure of yeast DPP III representing a prototype for the M49 family of metalloproteases was resolved by Baral et al. [15]. It shows a novel protein fold with two domains forming a wide cleft containing the catalytic metal ion. However, the three-dimensional structure of zinc coordination $\left(\mathrm{His}^{460}, \mathrm{His}^{465}\right.$, and $\mathrm{Glu}^{517}$ ) and the catalytic active $\left(\mathrm{Glu}^{461}\right)$ residues are structurally conserved, 


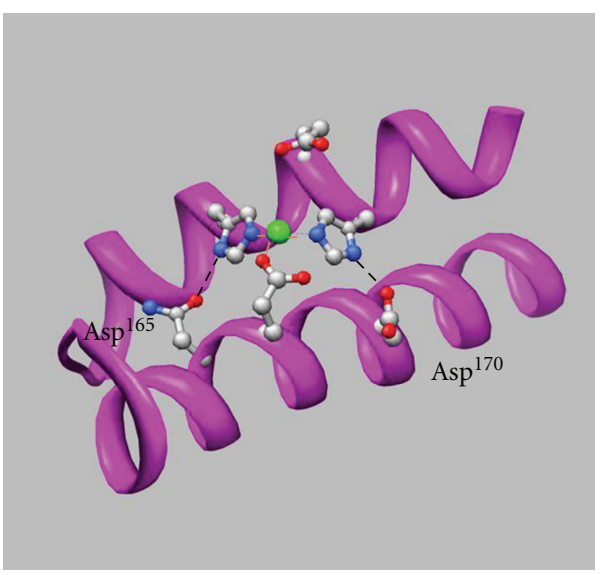

(a)

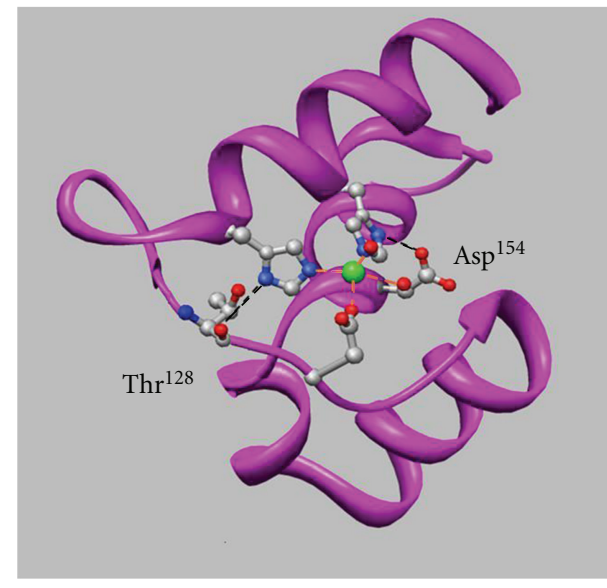

(b)

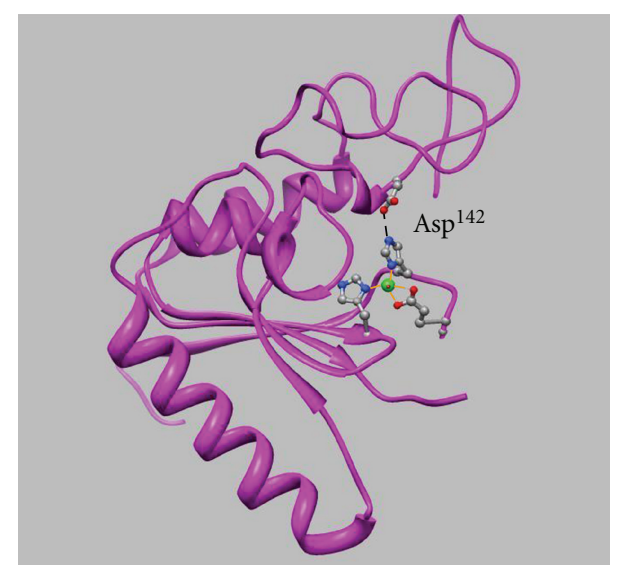

(c)

FIgure 2: Three-dimensional structures of the catalytic domain models for thermolysin ((a): PDB 1KEI), peptidyl-Lys metallopeptidase ((b): PDB 1GE6), and carboxypeptidase A ((c): PDB 1YME). The zinc ion is shown as a green sphere, and amino acid side chains are shown as sticks colored red for oxygen, blue for nitrogen, and silver for carbon. Hydrogen bonds are indicated by dashed lines.
TABLE 2: Kinetic parameters for the hydrolysis of Arg-Arg-NA, zinc contents, and zinc dissociation constants of wild-type and mutated rat DPP IIIs.

\begin{tabular}{lccc}
\hline Enzymes & $\begin{array}{c}k_{\mathrm{cat}} / K_{M} \times 10^{-4} \\
\left(\mathrm{M}^{-1} \mathrm{~s}^{-1}\right)\end{array}$ & $\begin{array}{c}\text { Zinc content } \\
(\mathrm{mol} / \mathrm{mol} \text { of } \\
\text { protein })\end{array}$ & $\begin{array}{c}\text { Zinc dissociation } \\
\text { constant }(\mathrm{M})\left(K_{d}\right)\end{array}$ \\
\hline Wild-type & $73.6 \pm 6.9$ & $1.02 \pm 0.15$ & $(4.5 \pm 0.1) \times 10^{-13}$ \\
E507D & $22.8 \pm 1.9$ & $0.65 \pm 0.07$ & $(1.0 \pm 0.2) \times 10^{-11}$ \\
E507A & $4.43 \pm 0.41$ & $0.29 \pm 0.04$ & $(1.0 \pm 0.2) \times 10^{-8}$ \\
E512D & $21.0 \pm 0.19$ & $0.45 \pm 0.06$ & $(1.4 \pm 0.1) \times 10^{-12}$ \\
E512A & $2.45 \pm 0.28$ & $0.08 \pm 0.01$ & $(2.6 \pm 0.7) \times 10^{-9}$ \\
\hline
\end{tabular}

${ }^{a}$ Values are means \pm SD of two separately prepared enzymes with duplicate determinations.

similar to those presented in many metalloproteases, such as thermolysin [13]. The HELLGH motif and the third ligand $\left(\mathrm{Glu}^{517}\right)$ of DPP III construct a helix $\alpha 14$ and a helix $\alpha 16$, respectively [15]. The $3 \mathrm{D}$ structure of DPP III is similar to that of thermolysin [13] or leukotriene $\mathrm{A}_{4}$ hydrolase [16], the zinc-binding domain of which is constructed of two $\alpha$ helixes, for HExxH (containing two zinc ligands) and $\mathrm{xNEx}$ (third ligand).

Figure 1 shows the superimposition of the active sites of rat DPP III and thermolysin. The helix $\alpha 14$ of DPP III has a slightly larger loop than that of thermolysin, and the glutamic acid on the motif comes close to zinc ion comparing with the glutamic acid on the normal helix of thermolysin $[13,17]$.

\section{Stabilization of the Coordination between Ligands and Metal}

In the 3D structural model of the zinc-binding domain of many zinc enzymes-neprilysin [18], thermolysin [13], carboxypeptidase A [19], leukotriene $\mathrm{A}_{4}$ hydrolase [16], aspzincin [20], and DPP III [17] — the His, His, and Glu residues that coordinate with the zinc ion are engaged in hydrogen bonds with one or two acidic amino acid residues (Glu or Asp) or other carbonyl oxygen atoms (Table 1). 3D structural models of catalytic domains of thermolysin (PDB: 1KEI), peptidyl-Lys metallopeptidase (PDB: 1GE6), and carboxypeptidase A (PDB: 1YME) are shown in Figure 2. In thermolysin (a), the oxygen atoms of Asp $^{165}$ and $A s p^{170}$ are engaged in hydrogen bonding with the nitrogen atoms of $\mathrm{His}^{146}$ and His ${ }^{142}$, respectively. Asp ${ }^{154}$ and $\mathrm{Thr}^{128}$ of peptidyl-Lys metalloendopeptidase (b) and Asp ${ }^{142}$ of carboxypeptidase A (c) are also engaged in hydrogen bonding with $\mathrm{His}^{117}$, $\mathrm{His}^{121}$, and $\mathrm{His}^{69}$, respectively. It was proved through the mutational studies of rat DPP III that this network of hydrogen bonds close to the zinc-binding motif plays an important role in stabilizing the coordination of the zinc ion to the protein [17]. The hydrogen bonds surrounding the zinc-binding motif of rat DPP III are shown in Figure 3, and the kinetic parameters, zinc contents and zinc dissociation constants of the several mutants are shown in Table 2. The replacement of $\mathrm{Glu}^{507}$ and $\mathrm{Glu}^{512}$, the oxygen atoms of which bind with the nitrogen atoms of $\mathrm{His}^{455}$ and 


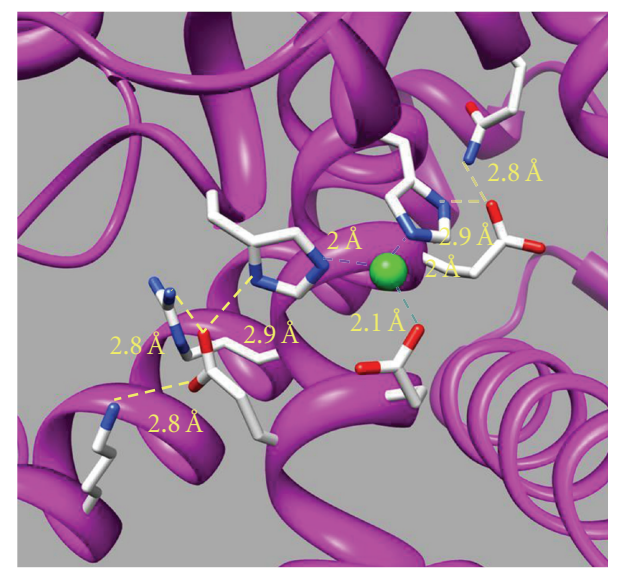

FIgure 3: Molecular modeling of the catalytic site of rat DPP III. The model was generated as a template of the human DPP III crystal structure [39]. The zinc ion is shown as a green sphere, and amino acid side chains are shown as sticks colored red for oxygen, blue for nitrogen, and white for carbon. Metal coordinates in light blue and hydrogen bonds in yellow are indicated by dashed lines.

$\mathrm{His}^{450}$, respectively, increases the dissociation constants by factors of $10 \sim 10^{5}$ and correlatively reduces the zinc contents and enzyme activities. The hydrogen bonds between acidic amino acid residues and zinc ligands (His, His, and Glu) may stabilize the coordination of the zinc ion with the protein of the metalloprotease.

\section{Metal Substitutions of Monozinc Metalloproteases}

Almost all metalloproteases are monozinc enzymes. Some enzymes contain two zinc ions for catalytic domains, for example, human renal dipeptidase [36], and a few are dicobalt or dimanganese enzymes, for example, Pyrococcus furiosus methionine aminopeptidase [37] or Escherichia coli proline aminopeptidase [38], respectively.

The zinc in numerous zinc metalloproteases has been substituted by several divalent cations. The cobalt(II)- or manganese(II)-substituted enzymes showed nearly restored catalytic activity or even excess activity from apoenzyme, as seen in Table 3.

Gomis-Rüth et al. [5] demonstrated in the metal substitution studies of astacin that $\mathrm{Cu}$ (II)-astacin displays enzyme activity of about $37 \%$, while $\mathrm{Ni}(\mathrm{II})$ - and $\mathrm{Hg}$ (II)astacin were almost inactive. In the crystal structure of $\mathrm{Cu}$ (II)-astacin, the metal ion is pentacoordinated with His $^{92}$, His ${ }^{96}$, His ${ }^{102}$, Tyr ${ }^{149}$, and $\mathrm{H}_{2} \mathrm{O}$, as in native $\mathrm{Zn}(\mathrm{II})$ astacin or $\mathrm{Co}$ (II)-astacin; however, in the $\mathrm{Ni}$ (II)-astacin or $\mathrm{Hg}$ (II)-astacin, the metal ion is hexacoordinated with an additional solvent molecule or tetracoordinated with no ordered solvent molecule, respectively [5]. The restoration of catalytic activity in these substituted astacins was shown to be dependent on the metal coordination structure [5].

Meanwhile, almost all $\mathrm{Cu}(\mathrm{II})$-substituted enzymes, such as thermolysin $[7,8]$, carboxypeptidase A [6], aminopeptidase B [22], or endopeptidase from Lactococcus lactis [30], show only partial activation or very low activities. The reason why these $\mathrm{Cu}(\mathrm{II})$ enzymes do not demonstrate catalytic activities may be that the coordination geometry of $\mathrm{Cu}$ (II) is more rigid than that of $\mathrm{Zn}$ (II) or $\mathrm{Co}(\mathrm{II})$.

In the case of DPP III, $\mathrm{Co}^{2+}-\mathrm{Ni}^{2+}$ - and $\mathrm{Cu}^{2+}-\mathrm{DPP}$ IIIs showed comparable catalytic activities to $\mathrm{Zn}^{2+}$-DPP III; the kinetic parameters are shown in Table 4 [9]. DPP III shows high flexibility of the metal ion for the catalytic activity compared with thermolysin or aminopeptidase B. Thermolysin or aminopeptidase $\mathrm{B}$ is a subclan MA (E) metalloprotease containing an $\mathrm{HExxH}-\mathrm{aa}_{\mathrm{n}}-\mathrm{E}$ motif, and the $3 \mathrm{D}$ structure of the active domain is very similar to that of DPP III described above. The zinc ion in a subclan MA (E) metalloprotease or DPP III is tetracoordinated with three ligands (His, His, and Glu) and a water molecule. The metal-substituted $\left(\mathrm{Co}^{2+}, \mathrm{Cu}^{2+}\right.$, or $\left.\mathrm{Ni}^{2+}\right)$ DPP III may have the same tetrahedral coordination structure as $\mathrm{Zn}^{2+}$ DPP III, so these enzymes are able to maintain the catalytic activity. The zinc in del-DPP III, whose active site converted into $\mathrm{HExxH}$, was substituted with $\mathrm{Co}^{2+}, \mathrm{Ni}^{2+}$, or $\mathrm{Cu}^{2+}$ to investigate the grounds for activation of the $\mathrm{Cu}^{2+}$-DPP III [10]. The $\mathrm{Co}^{2+}$-del-DPP III and $\mathrm{Ni}^{2+}$-del-DPP III showed comparable catalytic activity to that of $\mathrm{Zn}^{2+}$-del-DPP III, while the $\mathrm{Cu}^{2+}$-del-DPP III showed no catalytic activity, as in the case of thermolysin or aminopeptidase B [8-10].

The EPR (electron paramagnetic resonance) parameters of various $\mathrm{Cu}^{2+}$-substituted metalloproteases are shown in Table 5. Each parameter is exactly alike between DPP III and thermolysin, aminopeptidase B, or del-DPP III [8-10, 22]. The results show that the $\mathrm{Cu}(\mathrm{II})$ coordination structures of the $\mathrm{HExxH}-\mathrm{aa}_{\mathrm{n}}-\mathrm{E}$ and $\mathrm{HExxxH}-\mathrm{aa}_{52}-\mathrm{E}$ motifs are very similar.

In the superimposition of the $3 \mathrm{D}$ structure models of active sites of DPP III and del-DPP III, the $\alpha$-helix of DPP III, which is abnormally composed of 5 amino acid residues per one turn of the $\alpha$-helix, is a larger loop than that of del-DPP III, the same as the case for the superimposition of the active sites of DPP III and thermolysin (Figure 1). The coordination geometries of the two enzymes are similar, while the position of $\mathrm{Glu}^{451}$, which is essential for the enzyme activity, is slightly closer to the copper ion in DPP III than in del-DPP III. The distances of oxygen atoms of the $\mathrm{Glu}^{451}$ residues of del-DPP III and wild-type DPP III are $4.8 \AA$ and $3.2 \AA$ from the zinc ion, respectively. $\mathrm{Zn}$ (II) coordination geometry is flexible, so both wild-type and del-DPP IIIs could have catalytic activity. However, the oxygen atom of $\mathrm{Glu}^{451}$ in $\mathrm{Cu}(\mathrm{II})$-del-DPP III is not able to bind to the oxygen atom of the water molecule that is coordinated with the copper ion because the $\mathrm{Cu}$ (II) coordination geometry is very rigid. Therefore, the catalytic activity of $\mathrm{Cu}$ (II)-del-DPP III was diminished.

Some other $\mathrm{Cu}(\mathrm{II})$-substituted enzymes, for example, aminopeptidase Ey [21], vibriolysin [40], hyicolysin [32], and Legionella metalloendopeptidase [33], were shown to have enzyme activities. These enzymes are all classified in subclan MA (E), the same as thermolysin or aminopeptidase B. The metal coordination structures of these enzymes have not been shown in detail; however, the catalytic domain may be more flexible than that of thermolysin or aminopeptidase $\mathrm{B}$, in the same way as $\mathrm{Cu}(\mathrm{II})$-substituted DPP III. 
TABLE 3: Reactivated Co(II) and Mn(II) enzymes substituted from apo-metalloproteases.

\begin{tabular}{lcccl}
\hline Clan & Subclan & Name of enzyme & $\mathrm{Replaced} \mathrm{Ion}$ & Reference \\
\hline MA & E & Aminopeptidase Ey & $\mathrm{Co}^{2+}, \mathrm{Mn}^{2+}$ & Tanaka and Ichishima [21] \\
MA & E & Aminopeptidase B & $\mathrm{Co}^{2+}$ & Hirose et al. [22] \\
MA & E & Saccharolysin & $\mathrm{Co}^{2+}, \mathrm{Mn}^{2+}$ & Achstetter et al. [23] and Büchler et al. [24] \\
MA & E & Lysyl aminopeptidase & $\mathrm{Co}^{2+}, \mathrm{Mn}^{2+}$ & Klein et al. [25] \\
MA & E & Oligopeptidase F & $\mathrm{Co}^{2+}, \mathrm{Mn}^{2+}$ & Yan et al. [26] and Monnet et al. [27] \\
MA & E & Mycolysin & $\mathrm{Co}^{2+}, \mathrm{Mn}^{2+} \mathrm{Co}^{2+}$ & Chang and Lee [28], and Holmquist and Vallee \\
MA & E & Oligopeptidase O & $(200 \%), \mathrm{Mn}^{2+}(10 \%)$ & [29] \\
MA & E & Hyicolysin & $\mathrm{Co}^{2+}$ & Tan et al. [30] and Baankreis et al. [31] \\
ME & E & Legionella & $\mathrm{Co}^{2+}$ & Ayora and Götz [32] \\
MA & A & metalloendopeptidase & $\mathrm{Mn}^{2+}(69 \%)$ & Dreyfus and Iglewski [33] \\
MA & M & Epralysin & $\mathrm{Co}^{2+}(58 \%)$ & Diermayr et al. [34] \\
MA & M & Astacin & $\mathrm{Co}^{2+}(140 \%)$ & Gomis-Rüth et al. [5] \\
MA & M & MEPa (Gfb MEP & $\mathrm{Co}^{2+}$ & Nonaka et al. [35] \\
\hline
\end{tabular}

${ }^{\mathrm{a}}$ Peptidyl-Lys metallopeptidase; ${ }^{\mathrm{b}}$ Grifola frondosa; ${ }^{\mathrm{c}}$ Pleurotus ostreatus.

TABLE 4: Kinetic parameters for the hydrolysis of Arg-Arg-NA and metal contents of various metal-DPP IIIs.

\begin{tabular}{lcccc}
\hline Enzyme & $\begin{array}{c}K_{M} \\
\left(\times 10^{-5} \mathrm{M}\right)\end{array}$ & $\begin{array}{c}k_{\mathrm{cat}} \\
\left(\mathrm{s}^{-1}\right)\end{array}$ & $\begin{array}{c}k_{\mathrm{cat}} / K_{M} \\
\left(\times 10^{4} \mathrm{M}^{-1} \mathrm{~s}^{-1}\right)\end{array}$ & $\begin{array}{c}\text { Metal } \\
\text { content } \\
(\mathrm{mol} / \mathrm{mol} \\
\text { of protein })\end{array}$ \\
\hline $\mathrm{Zn}^{2+}$-DPP III & $\begin{array}{c}8.1 \\
( \pm 1.0)\end{array}$ & $\begin{array}{c}7.1 \\
( \pm 0.2)\end{array}$ & 8.8 & $\begin{array}{c}0.8 \\
( \pm 0.1)\end{array}$ \\
$\mathrm{Co}^{2+}$-DPP III & $\begin{array}{c}( \pm 2 \\
( \pm 0.9)\end{array}$ & $\begin{array}{c}7.0 \\
( \pm 0.1)\end{array}$ & 8.5 & $\begin{array}{c}1.0 \\
( \pm 0.1)\end{array}$ \\
$\mathrm{Cu}^{2+}$-DPP III & $\begin{array}{c}( \pm 9 \\
( \pm 1.1)\end{array}$ & $\begin{array}{c}10.1 \\
( \pm 0.3)\end{array}$ & 10.2 & $\begin{array}{c}1.1 \\
( \pm 0.1)\end{array}$ \\
\hline
\end{tabular}

TABLE 5: EPR parameters of $\mathrm{Cu}^{2+}$ proteases.

\begin{tabular}{|c|c|c|c|}
\hline & $g_{\perp}$ & $g_{l l}$ & $A_{l l}\left(\times 10^{-4} \mathrm{~cm}^{-1}\right)$ \\
\hline $\mathrm{Cu}^{2+}-\mathrm{DPP}$ III ${ }^{\mathrm{a}}$ & 2.06 & 2.27 & 167 \\
\hline $\mathrm{Cu}^{2+}$-del-DPP III ${ }^{\mathrm{b}}$ & 2.06 & 2.27 & 161 \\
\hline $\mathrm{Cu}^{2+}$-thermolysin ${ }^{\mathrm{c}}$ & 2.06 & 2.26 & 163 \\
\hline $\mathrm{Cu}^{2+}$-aminopeptidase $\mathrm{B}^{\mathrm{d}}$ & 2.06 & 2.27 & 157 \\
\hline $\mathrm{Cu}^{2+}$-carboxypeptidase $\mathrm{A}^{\mathrm{e}}$ & 2.05 & 2.33 & 115 \\
\hline
\end{tabular}

References ${ }^{\mathrm{a}}[9],{ }^{\mathrm{b}}[10],{ }^{\mathrm{c}}[8],{ }^{\mathrm{d}}[22]$, and ${ }^{\mathrm{e}}[6]$.

\section{Conclusions}

In this paper, we compared metal flexibility with the geometry of metal coordination of metalloproteases, to investigate why DPP III shows metal tolerance. Metal substitution of $\mathrm{Zn}$ (II) by $\mathrm{Co}$ (II) or $\mathrm{Mn}$ (II) on metalloproteases generally maintains catalytic activity, because the metal coordination geometries of $\mathrm{Zn}(\mathrm{II}), \mathrm{Co}(\mathrm{II})$, and $\mathrm{Mn}(\mathrm{II})$ are flexible. Most
$\mathrm{Cu}$ (II)-substituted enzymes could not restore the catalytic activities, because the $\mathrm{Cu}$ (II) coordination geometry is very rigid. However, $\mathrm{Cu}(\mathrm{II})$-substituted DPP III showed the same catalytic activity as that of $\mathrm{Zn}$ (II)-DPP III. We then studied the metal flexibilities and metal coordination geometries of many metallopeptidases, especially DPP III and del-DPP III, but we could not prove a relation between the metal flexibility and the metal coordination geometry. The metal tolerance of DPP III might depend on the flexibility of the metal-binding motif, not on the metal coordination geometry. By comparison of the 3D structure of active sites of DPP III and del-DPP III, both coordination geometries are seen to be similar, while the positions of catalytic amino acid residues (Glu) on those zinc-binding motifs are slightly different. We conclude that the catalytic site of $\mathrm{Cu}$ (II)-DPP III could be flexible enough to form the catalytic complex, with substrate and $\mathrm{H}_{2} \mathrm{O}$.

\section{References}

[1] N. D. Rawlings and A. J. Barret, "Introduction: metallopeptidases and their clans," in Handbook of Proteolytic Enzyme, A. J. Barrett, N. D. Rawlings, and J. F. Woessner, Eds., pp. 231-268, Academic Press, San Diego, Calif, USA, 2nd edition, 2004.

[2] A. David, "Catalytic mechanisms for metallopeptidases," in Handbook of Proteolytic Enzyme, A. J. Barrett, N. D. Rawlings, and J. F. Woessner, Eds., pp. 268-289, Academic Press, San Diego, Calif, USA, 2nd edition, 1998.

[3] K. Fukasawa, K. M. Fukasawa, M. Kanai, S. Fujii, J. Hirose, and M. Harada, "Dipeptidyl peptidase III is a zinc metalloexopeptidase. Molecular cloning and expression," Biochemical Journal, vol. 329, no. 2, pp. 275-282, 1998.

[4] K. Fukasawa, K. M. Fukasawa, H. Iwamoto, J. Hirose, and M. Harada, "The HELLGH motif of rat liver dipeptidyl peptidase III is involved in zinc coordination and the catalytic activity 
of the enzyme," Biochemistry, vol. 38, no. 26, pp. 8299-8303, 1999.

[5] F. X. Gomis-Rüth, F. Grams, I. Yiallouros et al., "Crystal structures, spectroscopic features, and catalytic properties of cobalt(II), copper(II), nickel(II), and mercury(II) derivatives of the zinc endopeptidase astacin. A correlation of structure and proteolytic activity," Journal of Biological Chemistry, vol. 269, no. 25, pp. 17111-17117, 1994.

[6] R. C. Rosenberg, C. A. Root, P. K. Bernstein, and H. B. Gray, "Spectral studies of copper(II) carboxypeptidase A and related model complexes," Journal of the American Chemical Society, vol. 97, no. 8, pp. 2092-2096, 1975.

[7] A. F. Monzingo and B. W. Matthews, "Binding of Ncarboxymethyl dipeptide inhibitors to thermolysin determined by X-ray crystallography: a novel class of transitionstate analogues for zinc peptidases," Biochemistry, vol. 23, no. 24, pp. 5724-5729, 1984.

[8] I. Bertini, G. Canti, H. Kozlowski, and A. Scozzafava, "Spectroscopic characterization of copper(II) thermolysin," Journal of the Chemical Society Dalton Transactions, no. 8, pp. 12701273, 1979.

[9] J. Hirose, H. Iwamoto, I. Nagao et al., "Characterization of the metal-substituted dipeptidyl peptidase III (rat liver)," Biochemistry, vol. 40, no. 39, pp. 11860-11865, 2001.

[10] J. Hirose, H. Kamigakiuchi, H. Iwamoto et al., "The metalbinding motif of dipeptidyl peptidase III directly influences the enzyme activity in the copper derivative of dipeptidyl peptidase III," Archives of Biochemistry and Biophysics, vol. 431, no. 1, pp. 1-8, 2004.

[11] C. Mazzocco, K. M. Fukasawa, A. A. Raymond, and J. Puiroux, "Purification, partial sequencing and characterization of an insect membrane dipeptidyl aminopeptidase that degrades the insect neuropeptide proctolin," European Journal of Biochemistry, vol. 268, no. 18, pp. 4940-4949, 2001.

[12] "Homo sapiens dipeptidyl-peptidase 3 (DPP3), transcript variant 1, mRNA," NCBI Reference Sequence: NM 005700.3.

[13] B. W. Matthews, "Structural basis of the action of thermolysin and related zinc peptidases," Accounts of Chemical Research, vol. 21, no. 9, pp. 333-340, 1988.

[14] J. F. Medina, A. Wetterholm, O. Rådmark et al., "Leukotriene A4 hydrolase: determination of the three zinc-binding ligands by site-directed mutagenesis and zinc analysis," in Proceedings of the National Academy of Sciences of the United States of America, vol. 88, no. 17, pp. 7620-7624, 1991.

[15] P. K. Baral, N. Jajčanin-Jozić, S. Deller, P. Macheroux, M. Abramić, and K. Gruber, "The first structure of dipeptidylpeptidase III provides insight into the catalytic mechanism and mode of substrate binding," Journal of Biological Chemistry, vol. 283, no. 32, pp. 22316-22324, 2008.

[16] M. M. G. M. Thunnissen, P. Nordlund, and J. Z. Haeggström, "Crystal structure of human leukotriene A4 hydrolase, a bifunctional enzyme in inflammation," Nature Structural Biology, vol. 8, no. 2, pp. 131-135, 2001.

[17] K. M. Fukasawa, J. Hirise, T. Hata, and Y. Ono, "In rat dipeptidyl peptidase III, His568 is essential for catalysis, and Glu507 or Glu512 stabilizes the coordination bond between His455 or His450 and zinc ion," Biochimica et Biophysica Acta, vol. 1804, pp. 2063-2069, 2010.

[18] C. Oefner, A. D'Arcy, M. Hennig, F. K. Winkler, and G. E. Dale, "Structure of human neutral endopeptidase (neprilysin) complexed with phosphoramidon," Journal of Molecular Biology, vol. 296, no. 2, pp. 341-349, 2000.
[19] D. C. Rees, M. Lewis, and W. N. Lipscomb, "Refined crystal structure of carboxypeptidase A at 1.54 A resolution," Journal of Molecular Biology, vol. 168, no. 2, pp. 367-387, 1983.

[20] T. Hori, T. Kumasaka, M. Yamamoto et al., "Structure of a new 'aspzincin' metalloendopeptidase from Grifola frondosa: implications for the catalytic mechanism and substrate specificity based on several different crystal forms," Acta Crystallographica Section D, vol. 57, no. 3, pp. 361-368, 2001.

[21] T. Tanaka and E. Ichishima, "Molecular properties of aminopeptidase Ey as a zinc-metalloenzyme," International Journal of Biochemistry, vol. 25, no. 11, pp. 1681-1688, 1993.

[22] J. Hirose, T. Ohsaki, N. Nishimoto et al., "Characterization of the metal-binding site in aminopeptidase B," Biological and Pharmaceutical Bulletin, vol. 29, no. 12, pp. 2378-2382, 2006.

[23] T. Achstetter, C. Ehmann, and D. H. Wolf, "Proteinase $y s c \mathrm{D}$. Purification and characterization of a new yeast peptidase," Journal of Biological Chemistry, vol. 260, no. 8, pp. 4585-4590, 1985.

[24] M. Büchler, U. Tisljar, and D. H. Wolf, "Proteinase $y s c \mathrm{D}$ (oligopeptidase $y s c \mathrm{D}$ ). Structure, function and relationship of the yeast enzyme with mammalian thimet oligopeptidase (metalloendopeptidase, EP 24.15)," European Journal of Biochemistry, vol. 219, no. 1-2, pp. 627-639, 1994.

[25] J. R. Klein, U. Klein, M. Schad, and R. Plapp, "Cloning, DNA sequence analysis and partial characterization of pepN, a lysyl aminopeptidase from Lactobacillus delbrueckii ssp. lactis DSM7290," European Journal of Biochemistry, vol. 260, pp. 4585-4590, 1993.

[26] T. R. Yan, N. Azuma, S. Kaminogawa, and K. Yamauchi, "Purification and characterization of substrate-size-recognizing metalloendopeptidase from Streptococcus cremoris H61," Applied and Environmental Microbiology, vol. 53, pp. 22962302, 1987.

[27] V. Monnet, M. Nardi, A. Chopin, M. C. Chopin, and J. C. Gripon, "Biochemical and genetic characterization of PepF, an oligopeptidase from Lactococcus lactis," Journal of Biological Chemistry, vol. 269, no. 51, pp. 32070-32076, 1994.

[28] P. C. Chang and Y. H. W. Lee, "Extracellular autoprocessing of a metalloprotease from Streptomyces cacaoi," Journal of Biological Chemistry, vol. 267, no. 6, pp. 3952-3958, 1992.

[29] B. Holmquist and B. L. Vallee, "Metal substitutions and inhibition of thermolysin: spectra of the cobalt enzyme," Journal of Biological Chemistry, vol. 249, no. 14, pp. 46014607, 1974.

[30] P. S. T. Tan, K. M. Pos, and W. N. Konings, "Purification and characterization of an endopeptidase from Lactococcus lactis subsp. cremoris Wg2," Applied and Environmental Microbiology, vol. 57, no. 12, pp. 3593-3599, 1991.

[31] R. Baankreis, S. Van Schalkwijk, A. C. Alting, and F. A. Exterkate, "The occurrence of two intracellular oligoendopeptidases in Lactococcus lactis and their significance for peptide conversion in cheese," Applied Microbiology and Biotechnology, vol. 44, no. 3-4, pp. 386-392, 1995.

[32] S. Ayora and F. Götz, "Genetic and biochemical properties of an extracellular neutral metalloprotease from Staphylococcus hyicus subsp. hyicus," Molecular and General Genetics, vol. 242, no. 4, pp. 421-430, 1994.

[33] L. A. Dreyfus and B. H. Iglewski, "Purification and characterization of an extracellular protease of Legionella pneumophila," Infection and Immunity, vol. 51, no. 3, pp. 736-743, 1986.

[34] P. Diermayr, S. Kroll, and H. Klostermeyer, "Influence of EDTA and metal ions on a metalloproteinase from Pseudomonas fluorescens biotype I," Biological Chemistry HoppeSeyler, vol. 368, no. 1, pp. 57-61, 1987. 
[35] T. Nonaka, Y. Hashimoto, and K. Takio, "Kinetic characterization of lysine-specific metalloendopeptidases from Grifola frondosa and Pleurotus ostreatus fruiting bodies," Journal of Biochemistry, vol. 124, no. 1, pp. 157-162, 1998.

[36] Y. Nitanai, Y. Satow, H. Adachi, and M. Tsujimoto, "Crystal structure of human renal dipeptidase involved in $\beta$-lactam hydrolysis," Journal of Molecular Biology, vol. 321, no. 2, pp. 177-184, 2002.

[37] T. H. Tahirov, H. Oki, T. Tsukihara et al., "High-resolution crystals of methionine aminopeptidase from Pyrococcus furiosus obtained by water-mediated transformation," Journal of Structural Biology, vol. 121, no. 1, pp. 68-72, 1998.

[38] M. C. J. Wilce, C. S. Bond, N. E. Dixon et al., "Structure and mechanism of a proline-specific aminopeptidase from Escherichia coli," Proceedings of the National Academy of Sciences of the United States of America, vol. 95, no. 7, pp. 34723477, 1998.

[39] E. Dobrovetsky, A. Dong, A. Seitova et al., "Crystal structure of human dipeptidyl peptidase III," in Structural Genomics Consortium (SGC), 2009.

[40] S. I. Miyoshi, K. Kawata, K. I. Tomochika, and S. Shinoda, "The hemagglutinating activity of Vibrio vulnificus metalloprotease," Microbiology and Immunology, vol. 43, no. 1, pp. 7982, 1999. 

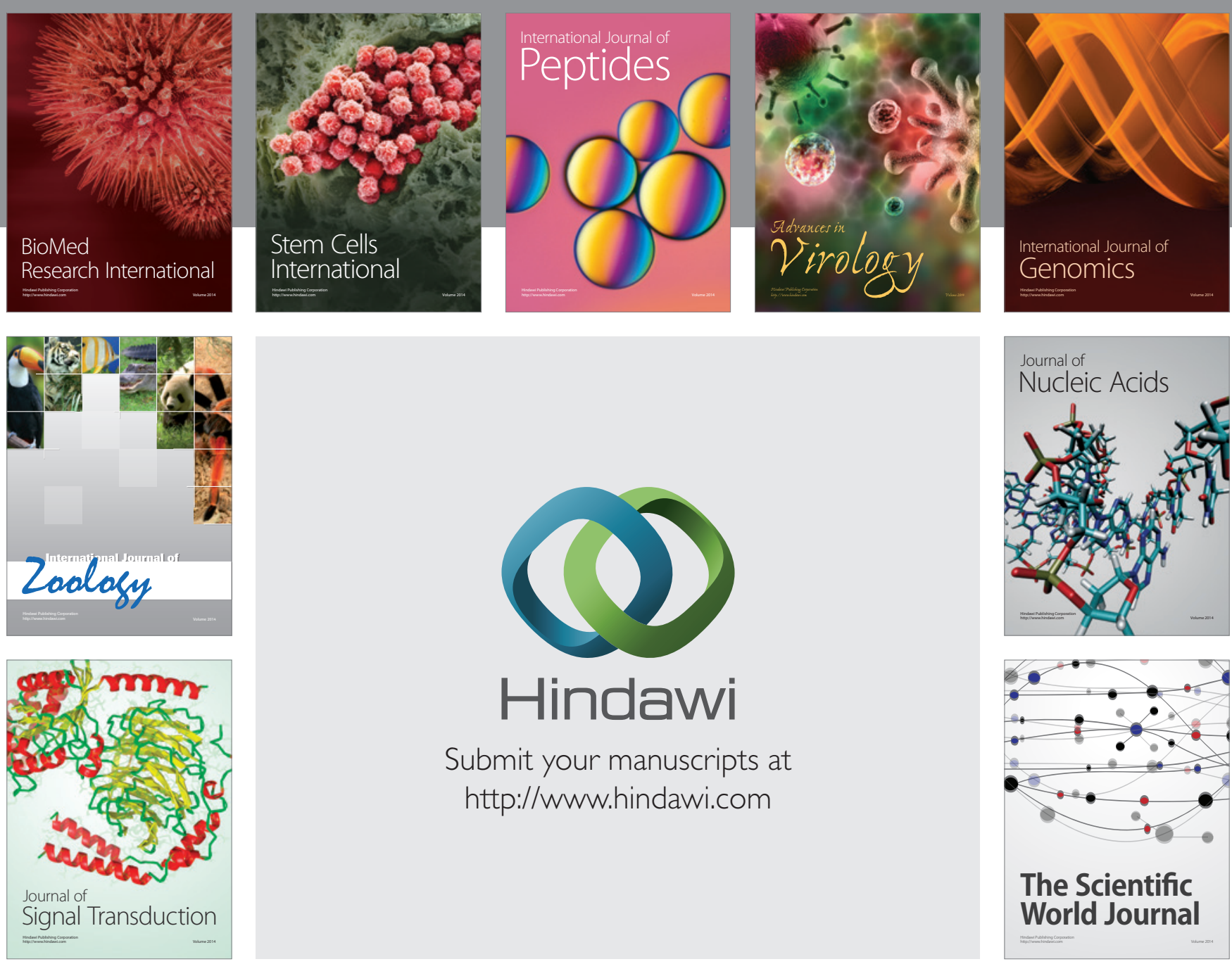

Submit your manuscripts at

http://www.hindawi.com
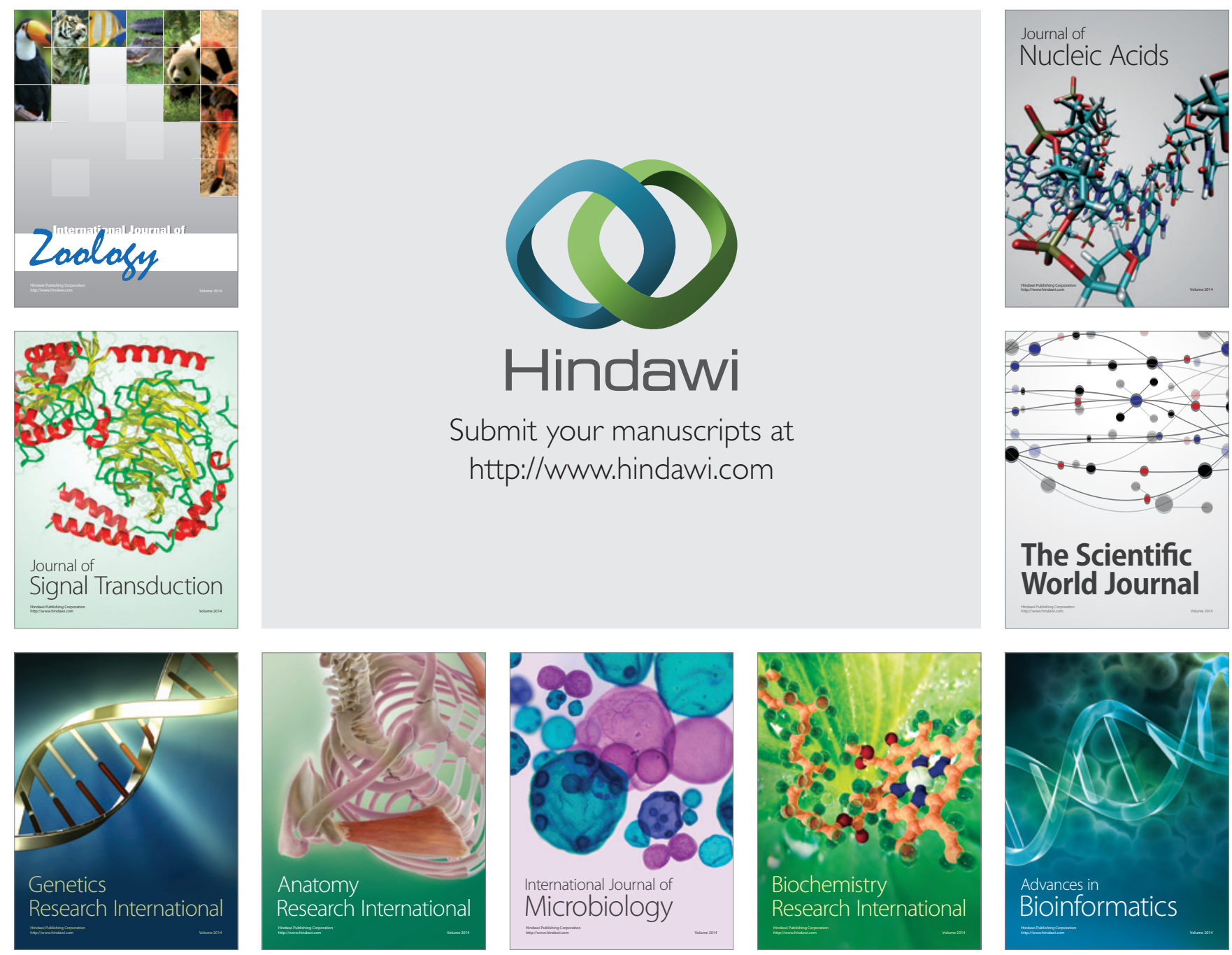

The Scientific World Journal
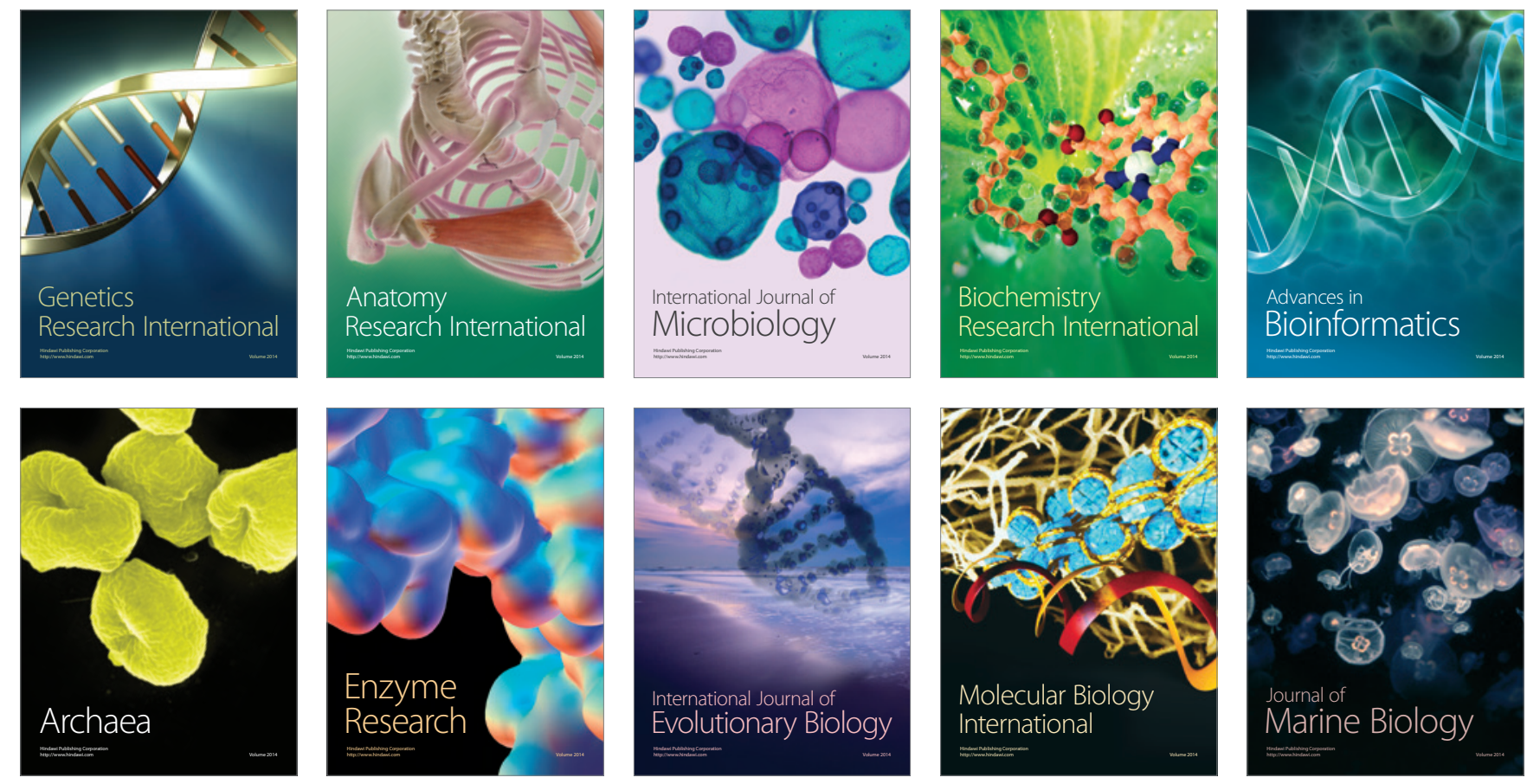